\title{
RECICLAGEM DE PNEUS: DISCUSSÃO DO IMPACTO DA POLÍTICA BRASILEIRA
}

\author{
Carlos Alberto Ferreira Lagarinhos ${ }^{1}$ \\ Jorge Alberto Soares Tenório ${ }^{2}$
}

\begin{abstract}
Resumo: Os pneus usados estão se tornando um problema mundial. O Brasil foi o primeiro país na América Latina a regulamentar a reciclagem de pneus. Após a aprovação da resolução CONAMA no $258 / 99$ que instituiu a responsabilidade do produtor e importador pelo ciclo total do produto, ocorreu um avanço na cadeia de reciclagem de pneus, sendo reciclados no período de 2002 a 2006, 805,26 mil toneladas de pneus inservíveis, o equivalente a 161,05 milhões de pneus de automóvel. Apesar de todo o esforço para o cumprimento das metas de reciclagem, os fabricantes de pneus e importadores de pneus usados não conseguiram cumprir as metas de reciclagem no período de 2003 a 2006. A resolução no 258/99 encontrase em revisão pelo CONAMA e IBAMA desde 2005. Fabricantes, reformadores, entidades ambientalistas e cimenteiras estão participando desta revisão. Neste trabalho serão apresentadas e comparadas as resoluções ambientais dos países membros da Comunidade Européia, Japão, Estados Unidos e Brasil, discutir as modificações da resolução no $258 / 99$ propostas pelos fabricantes, importadores, indústrias de cimento, e apresentar os resultados obtidos com a reciclagem no período de 2002 a 2006.
\end{abstract}

Palavras-chave: Reciclagem, pneus, política ambiental.

\begin{abstract}
The used tires are becoming a global problem. Brazil was the first country in Latin America to regulate the tires recycling. After CONAMA's resolution approval no ${ }^{258 / 99}$, which have established the responsibility of the producer and importer by the full cycle of the product, a progress occurred in the tires recycling chain, and in the period from 2002 to 2006, 805,26 thousand tons of unserviceable tires were recycled, what is equivalent to 161,05 million of automobile tires. Despite all the efforts to recycling goals accomplishment, the tire producers and reformers did not get to comply with the recycling objects from 2003 to 2006. The resolution n 258/99 has been in review by CONAMA and IBAMA since 2005. Manufacturers, reformers, environmental entities and cement industries are participating of this review. This work will be presented and compared to the environmental resolutions of the member countries of the European Community, Japan, The United States and Brazil, to discuss the changes proposals in the CONAMA's resolution by manufactures, importers, cement industries and present the results of the recycling during the period from 2002 to 2006.
\end{abstract}

Keywords: Recycling, Tires, Environmental Policy.

\footnotetext{
1 Escola Politécnica, Universidade de São Paulo - Departamento de Engenharia Metalúrgica e de Materiais, e-mail: clagarinhos@usp.br.

2 Escola Politécnica, Universidade de São Paulo - Departamento de Engenharia Metalúrgica e de Materiais, e-mail: jtenorio@usp.br.
} 


\section{INTRODUÇÃO}

Os pneus usados estão se tornando um problema mundial. O descarte de pneus cresce ano após ano em todo o mundo. No passado, pouca importância foi dada à disposição de pneus mesmo nos países mais desenvolvidos, os pneus usados eram descartados em enormes aterros, vales, rios, entre outros. Nos países emergentes, o problema era simplesmente ignorado e muitas vezes o destino final destes pneus eram aterros, rios, beira de estradas, entre outros.

A quantidade de pneus descartados e sua durabilidade no ambiente têm motivado a proposição de medidas mitigadoras dos impactos ambientais negativos e a realização de pesquisas em vários países, inclusive no Brasil.

A produção mundial de pneus novos em 2006 foi de 1,353 bilhôes em todo o mundo. Já o descarte de pneus usados chega a atingir, anualmente, a marca de quase 1 bilhão de unidades [1].

A produção mundial por região geográfica em 2006 foi: América do Norte, 231 milhōes; América do Sul e Central, 84 milhões; Europa, 405 milhōes; Oriente Médio e África, 51 milhões; Ásia e Oceania, 581 milhões de pneus novos [1].

Os países líderes na produção de pneus são: Estados Unidos, 199 milhões; Japão, 176 milhões; China, 165 milhões; Coréia, 82 milhōes; Alemanha, 75 milhões; França, 59 milhões [1].

Os Estados Unidos foi o maior fabricante pneus no mundo em 2006, produzindo $14,7 \%$; o Japão, 13\%; China, 12,2\%; Coréia do Sul, 6,1\%; Alemanha, 5,5\%; e França, 4,4\%. Os seis países juntos representaram $55,9 \%$ da produção mundial.

\subsection{DIRETRIZES APROVADAS NA COMUNIDADE EUROPÉIA}

Em resposta aos problemas ambientais e riscos de saúde causados pelas pilhas de pneus usados, a maioria dos paises desenvolvidos tem investigado diretrizes legais sobre este tópico. Regulamentações variam de país para país, mas o principal propósito dessas regulamentaçôes é fornecer um dispositivo ambientalmente seguro, limitando a quantidade de pneus usados armazenados em alguma dada localização e incentivar a reciclagem de pneus.

Durante a década de 1990, os pneus atraíam considerável atenção da Comissão dos países membros da Comunidade Européia para assegu- rar o seu controle e garantir a sua eliminação dos aterros. Várias tentativas foram realizadas em 1993 e 1994 para aprovar duas diretrizes que tratavam somente dos pneus, os dois projetos foram suspensos. Não existe uma legislação na Comunidade Européia que trate especificamente dos pneus, com exceção das Diretrizes de Aterros (1999/31/ $\mathrm{CE})$ que proíbe o descarte dos pneus inteiros e triturados nos aterros e a Diretriz (2000/53/CE) que identifica os pneus entre as partes removidas dos veículos durante a sua desmontagem, para garantir que eles não sejam descartados nos aterros. Assim, a gestão no final da vida útil dos pneus é determinada em nível de cada estado membro, e cada um concebeu a sua própria solução. As diferenças na política, as prioridades, as tecnologias disponíveis, recursos, a cultura ou a dimensão.

A seguir serão apresentadas as Diretrizes de aterros e dos veículos no final da vida útil [2]:

a) Diretrizes de aterros 1999/31/EC, de 26 de abril de 1999, define:

- qualquer outro tipo de tratamento dos resíduos, a disposição em aterros deve ser controlada e gerenciada de forma adequada, a fim de evitar ou reduzir os potenciais impactos negativos ao meio ambiente e os riscos a saúde;

- proíbe a disposição de pneus inteiros em aterros desde julho de 2003 e pneus triturados até julho de 2006, com exceção de pneus com diâmetro acima de 1400 mm e pneus de bicicleta;

- esta proibição aplica-se a pneus de automóvel, ônibus, caminhão, motocicleta, aviōes e pneus maciços usados na indústria;

- permite a utilização de pneus inteiros em obras de engenharia nos aterros;

b) Diretrizes dos veículos no final da vida útil 2000/53/EC, de 18 de setembro de 2000:

- prevenção para os resíduos dos carros após o término da vida útil e formas de reutilização, recuperação e reciclagem dos veículos e seus componentes, com isso, reduzindo a disposição dos resíduos;

- proíbe a disposição de componentes e materiais, peças de reposição e peças trocadas, incluindo pneus;

- o objetivo para a reutilização e a recuperação deveria ser de $85 \%$ em 2006; 
- o objetivo para a reutilização e reciclagem deveria ser $80 \%$ do peso do veículo em 2006;

- o objetivo para a reutilização e a recuperação deve ser de $95 \%$ até 2015 .

Além das diretrizes para a reutilização, reciclagem e valorização energética dos componentes utilizados nos veículos no final da vida útil, foi criada a Norma ISO 22628 de 15 de fevereiro de 2002, que trata do método de cálculo da relação de recuperabilidade e reciclabilidade de veículos que dependem do projeto e das propriedades dos materiais dos veículos novos. Os pneus usados entram na classe de pré-tratamento e é suposto que podem ser reciclados, reutilizados ou ambos [3].

\subsection{RECICLAGEM DE PNEUS NOS ESTADOS UNIDOS}

Em 2003, a geração de pneus usados nos Estados Unidos foi de 290,19 milhões de pneus e reciclaram $80,35 \%$, ou seja, 233,16 milhões de pneus usados.

Entre 2003 a 2005, o total de pneus reciclados aumentou 24,4\%, 259,2 milhōes, representando $86,6 \%$ do total reciclado em 2005 [4].

O cálculo da quantidade de pneus descartados é baseado no mercado de reposição e dos pneus retirados dos carros, caminhōes e ônibus no final da vida útil. Em 2005 foram descartados 299,15 milhôes de pneus, ou seja, 1,01 pneus por habitante.

Em 2005, ocorreu uma expansão no mercado de reciclagem de pneus, os destinos mais representativos são: utilização de pneus como combustível alternativo e aplicações com a borracha reciclada. A figura 1 [4] mostra a disposição dos pneus usados nos Estados Unidos no período de 1990 a 2005. Após a implementação de legislações restritivas em vários estados, com relação ao descarte de pneus usados, e o avanço do estudo do processo de reciclagem de pneus, em 1990 o total de pneus descartados em aterros era de 1 bilhão de pneus, em 2005, 188 milhôes, ou seja, uma redução de $81,2 \%$.

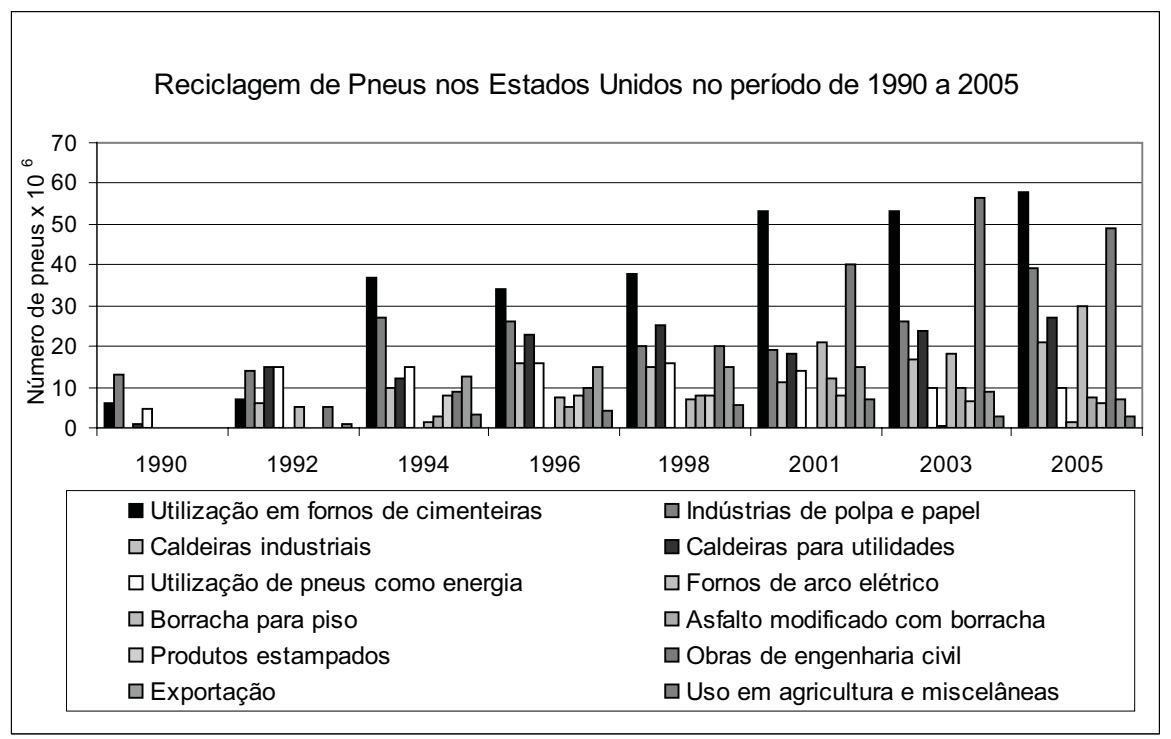

Figura 1 - Reciclagem de pneus nos Estados Unidos no período de 1990 a 2005, em quantidade de pneus [4].

Há estimativa que 2 a 3 bilhões de pneus inservíveis sejam armazenados ilegalmente ou abandonados em rios, ruas, aterros, entre outros, por todo os Estados Unidos. Este dado representa a geração acumulada de pneus inservíveis de aproximadamente dez anos [5].

As taxas de coleta para os pneus de passeio nos Estados Unidos variam de US\$ 0,25 a 2,50 por pneu de automóvel e de US\$ 3,50 a 4 por pneu de ônibus e caminhão, dependendo da legislação estadual. O Estado da Carolina do Norte cobra uma taxa de $2 \%$ do custo do pneu novo para coletar o pneu usado [6].

Alguns estados oferecem incentivos, subsídios e empréstimos para a melhoria dos processos existentes, desenvolvimentos de novos processos e mercados, tais como [6]: 
- reembolso dos subsídios para beneficio dos usuários finais dos pneus usados;

- subsídios e interesse por empréstimos para instalações de pré-tratamentos de pneus;

- subsídios para grandes testes com combustíveis alternativos (50\% do custo, acima de US\$ 30 mil);

- subsídios para a limpeza de pilhas de pneus usados em aterros;

- empréstimos e subsídios disponíveis para negócios realizados com pneus usados;

- $30 \%$ do imposto de renda disponível como crédito para companhias que gerenciam os resíduos, incluindo a redução, reciclagem, reutilização e equipamentos;

- desconto no imposto igual a $20 \%$ do custo de equipamentos para a reciclagem;

- financiamento de alternativas para aterros. Programas para proverem fundos e recursos para programas de redução e reciclagem;

- concessão de subsídios para processadores que permitam uma taxa de venda para o material processado de pneus usados;

- desconto no imposto para compra de equipamentos para a reciclagem, sendo: $15 \%$ do fundo disponível para recicladores em áreas rurais e 30\% do fundo disponível para novos negócios com a reciclagem de pneus usados;

- departamentos de saúde pública fornecem aos recicladores acima de US\$ 70/ tonelada de combustível derivado de pneus ou em produtos fabricados com materiais reciclados de pneus usados;

- subsídios e empréstimos para as operações com pneus usados.

Os cinco principais mercados para a reciclagem de pneus usados nos Estados Unidos são [4]:

- a valorização energética de pneus em 2005, utilizou 155,1 milhões de pneus usados, ou seja, 59,84\% do total reciclado. Existem 117 fábricas que utilizam pneus como combustível alternativo, entre elas: fornos de clínquer, caldeiras industriais, fábricas que transformam re- síduos em energia elétrica, e na indústria de papel;

- a utilização de pneus triturados na construção de rodovias, aterros, fossas sépticas e outras construções, utilizando 49,22 milhōes de pneus usados, ou seja, $19 \%$ do total reciclado. Os pneus nestas aplicações reduzem a vibração e o ruído, alternativas de baixo preço para controle da erosão do solo e desabamentos de encostas, e como sistema de drenagem de chorume;

- a utilização em superfícies esportivas, produtos moldados, playground e asfalto modificado com borracha. Consumiram 46,65 milhões de pneus usados em 2005 , o que representa $17,99 \%$ do total reciclado;

- a incorporação de pneus nos fornos de arco elétrico para a produção de aço com alto teor de carbono. Este mercado é único porque o carbono e o aço contidos nos pneus usados podem ser reciclados e usados como matéria-prima para a fabricação do aço. A perspectiva é a expansão deste novo mercado para os próximos dois anos. Em 2005, foram utilizados 1,34 milhôes de pneus, ou seja, $0,52 \%$ do total reciclado.

- a exportação de 6,87 milhões de pneus para a recauchutagem, o que corresponde a $2,65 \%$ do total reciclado.

Em 2005, a valorização energética e a construção civil foram responsáveis pela utilização de $78,83 \%$ dos pneus reciclados. Foram descartados em aterros em 19 estados, 42,42 milhões de pneus, que representa $14 \%$ do total gerado. Ocorreu um aumento de 63,65\%, quando comparado a 2003.

\subsection{RECICLAGEM DE PNEUS NA COMUNIDADE EUROPÉIA}

Os 25 estados membros da Comunidade Européia descartam anualmente aproximadamente 3,1 milhões de toneladas de pneus usados [2]. Os pneus radiais representam 95\% do mercado de pneus novos, e os convencionais ou diagonais, $5 \%$.

O peso médio dos pneus usados de automóvel, 6 a 7,2 kg; de caminhão e ônibus, 40 a 70 
$\mathrm{kg}$; agrícolas $85 \mathrm{~kg}$. O pneu no final da vida útil perde $20 \%$ em peso da banda de rodagem [7].

O passivo ambiental está estimado em 1 bilhão de pneus usados. Em 1992, 62\% dos pneus usados nos 12 países membros da Comunidade Européia eram descartados em aterros, $6 \%$ eram reutilizados e exportados, $13 \%$ reformados, $5 \%$ reciclados e $14 \%$ valorizados energeticamente [7].

Em 2002, a situação era completamente diferente nos 15 países membros da Comunidade Européia, os pneus usados eram: 11,4\% exportados, e reutilizados, $12,6 \%$ reformados, $25 \%$ reciclados, $24,4 \%$ valorizados energeticamente e $26,4 \%$ eram destinados para aterros.
A figura 2 mostra a reciclagem de pneus nos 27 países membros da Comunidade Européia até 2005 [2].

A projeção para os próximos anos é a redução contínua do descarte de pneus usados em aterros. Quase todos os países membros da Comunidade Européia têm criado diretrizes para a melhoria do processo de gerenciamento dos pneus usados com o objetivo de eliminar a disposição em aterros até 2010 [7-8].

Pode-se observar que a disposição em aterros em 2005 foi de 22\%, ou seja, 1,8\% menor quando comparado a 2004; a reutilização e a exportação, $8 \%$; a reforma $12 \%$. A valorização energética teve um aumento de 3,9\% e a reciclagem de $2,6 \%$ quando comparadas a 2004 [2].

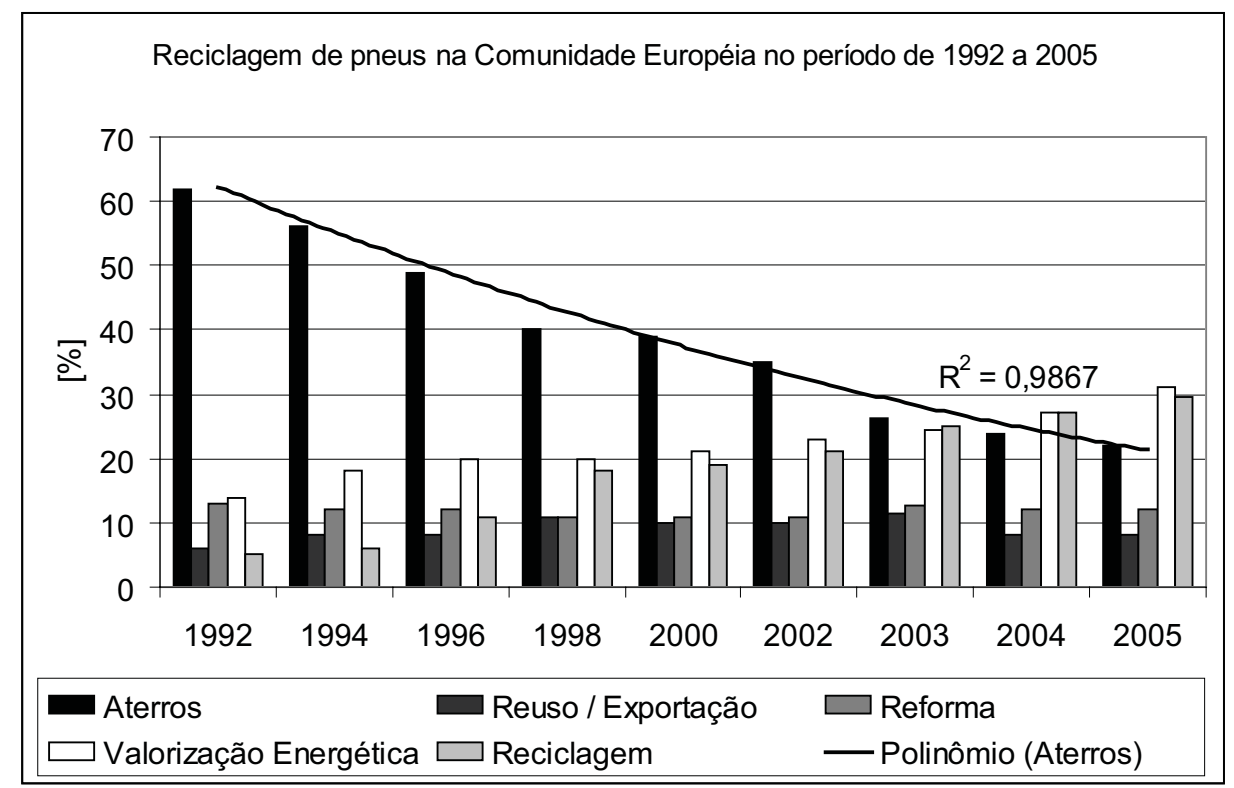

Figura 2 - Reciclagem de pneus nos países membros da Comunidade Européia no período de 1992 a 2005 [2].

Os cinco principais mercados para a reciclagem de pneus usados na Comunidade Européia são [7]:

- exportação de pneus usados para países emergentes. Esta prática deve ser limitada no futuro;

- recapagem e recauchutagem de pneus;

- produção de granulado de pneus usados, e seu uso, de acordo com as normas européias, na construção civil, aplicação em construção, reabilitação e fabricação de produtos industriais;
- valorização energética dos pneus usados em plantas de geração de energia, fornos de clínquer nas fábricas de cimento, indústrias de papel, substituindo o gás, óleo e carvão; e a pirólise

- Com a expansão de 15 para 25 países membros, a perspectiva da Comunidade Européia para a expansão do programa é de cerca de 1350 mil toneladas, ou seja, o equivalente a 225 milhões de pneus de automóvel ou 33,75 milhões de pneus de ônibus e caminhão, que serão tratados todos os anos. 
Nos países membros da Comunidade Européia, foram implantados três sistemas [9]: o mercado livre, o retorno com responsabilidade do fabricante e com taxas.

\subsubsection{Reciclagem de Pneus na Itália}

As principais tecnologias para a reutilização, recuperação e descarte de pneus usados na Itália são: ressulcagem, reforma, reciclagem de materiais, valorização energética, descarte e armazenamento [10].

A ressulcagem prolonga a vida útil dos pneus de ônibus e caminhôes. Esta prática não é possível para os pneus de automóvel porque o projeto do pneu não permite o aumento da distância entre o fundo da cavidade da banda de rodagem e a lona de aço.

A reforma aumenta a vida útil dos pneus e aproveita $80 \%$ do material original do pneu. Nos países membros do OECD (Organização para a Cooperação e o Desenvolvimento Econômico) a produção de pneus reformados tem um bom desenvolvimento e representa uma sólida realidade industrial.

$\mathrm{Na}$ reciclagem, os pneus usados, inteiros ou triturados, podem ser reutilizados para inúmeras aplicaçōes:

- nos trabalhos de engenharia civil por possuir propriedades de amortecimento, por exemplo: barreiras para estradas, absorventes acústicos para paredes e defensas marítimas;

- como isolante nas fundações das construções e materiais que são base para estradas;

- como material de recobertura para aplicações agrícolas e para o descarte;

- como refúgio artificial para proteção do habitat dos peixes;

- pode ser utilizado como material para a produção de tapetes, acessórios para vestuário como cintos, bolsas, entre outras aplicações.

Outra forma de reciclagem dos pneus inservíveis é a produção de pó-de-borracha, granulados, a realização da pirólise e a produção da borracha regenerada.

O pó ou granulados de borracha são materiais que podem ser utilizados:
- em compostos para diversas aplicações na indústria da borracha, com exceção dos pneus novos;

- em pisos industriais, tapetes automotivos, superfícies esportivas;

- utilizados para impermeabilizar telhados;

- podem ser utilizados na composição do asfalto borracha;

- como misturas de borrachas e materiais termoplásticos, entre outras aplicações.

A pirólise é um processo que aproveita os materiais constituintes dos pneus. Os componentes orgânicos obtidos dos pneus inservíveis são recuperados pelo aquecimento parcial ou total na ausência de oxigênio. Deste processo pode-se obter o óleo, o negro de fumo, gases gerados pelo processo e o aço. $\mathrm{O}$ óleo pode ser utilizado como combustível. O negro de fumo pode ser utilizado na indústria da borracha, o aço na indústria siderúrgica.

A borracha regenerada é obtida através de um processo químico. São utilizados granulados de borracha, óleo, água e produtos químicos. O produto obtido é utilizado junto com borrachas virgens para a produção de diversos produtos de borracha.

$\mathrm{Na}$ valorização energética os pneus inservíveis são utilizados como combustíveis, devido o poder calorífico ser igual ao do carvão. Os pneus podem ser utilizados inteiros ou triturados, para a produção de vapor, eletricidade, cimento, cal, papel e aço.

Os pneus podem ser utilizados como uma fonte principal ou secundária de energia para a produção de vapor, eletricidade, cimento, cal, papel, aço e também como um aditivo para a combustão de resíduos domésticos.

Podem, ainda, ser alimentados inteiros ou triturados em fornos de clínquer nas fábricas de cimento. A alta temperatura permite a combustão completa dos pneus e o aço contido nos pneus é incorporado ao clínquer durante o seu co-processamento.

Nos fornos de cal os pneus inservíveis são utilizados como combustível com ou em conjunto com outros resíduos, em fornos de calcinação do $\mathrm{CaCO}_{3}$. O processo de utilização dos pneus inservíveis em fornos de cal é mais simples quando comparados com os fornos de clínquer, mas 
o tipo de resíduo influência a qualidade do $\mathrm{CaO}$ obtido.

Os pneus podem ser utilizados como combustível em caldeiras que geram vapor para o processo de reforma e para a fabricação de pneus. O vapor é utilizado nas prensas de vulcanização e autoclaves.

Os pneus inservíveis são utilizados em algumas usinas projetadas para a geração da energia elétrica. Durante a combustão, os pneus são colocados em um leito fluidizado. As cinzas geradas pelo processo de combustão caem sobre um sistema de transporte e no final do processo são recolhidos em silos. Existe um sistema para a retirada do aço dos pneus queimados. A caldeira gera o vapor que movimenta a turbina gerando energia elétrica. $\mathrm{Na}$ Itália, existem 3 fábricas desde 2000, que produzem cerca de $70 \mathrm{GWh}$ [10].

A incineração de pequenas quantidades de pneus inservíveis, juntamente com outros resíduos é uma prática comum na Itália. A porcentagem de pneus inservíveis não deve ser superior a $10 \%$ em peso. Os pneus inservíveis ajudam a balancear o poder calorífico nos incineradores quando misturados com outros resíduos. Um outro tipo de processo utilizado é o da gaseificação, que permite uma utilização dos gases produzidos por uma combustão controlada.

Os aterros só devem ser utilizados para os pneus inservíveis quando não existem outras soluções para a reciclagem e/ou valorização energética. Em alguns países é proibida o descarte de pneus inservíveis em aterros. Os pneus quando triturados podem ser usados em aterros com as seguintes vantagens: evitar a erosão lateral, a fim de permitir a drenagem e líquidos do aterro, baixo investimento.

Os depósitos podem ser utilizados como uma forma temporária para a estocagem dos pneus inservíveis.

Podemos verificar na figura 3 [10] que na Itália em 2005 foram recicladas 384 mil toneladas de pneus, o equivalente a 64 milhões de pneus de automóvel. A valorização energética em fornos de clínquer e geração de energia corresponde a 39\%, a reciclagem $22 \%$, a reforma $15 \%$, a reutilização $13 \%$, a exportação $9 \%$ e o descarte $2 \%$ do total reciclado.

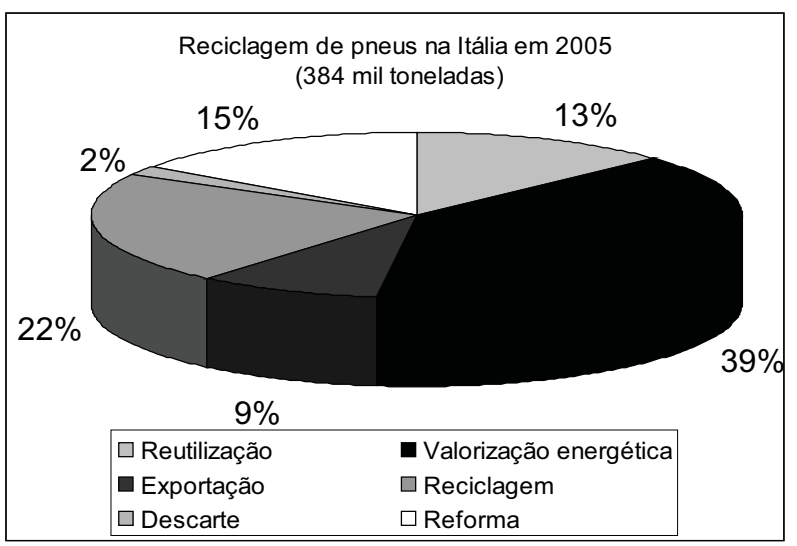

Figura 3 - Disposição dos pneus usados na Itália em 2005 [10].

\subsection{RECICLAGEM DE PNEUS NO JAPÃO}

No Japão, em 2002, foram produzidos 168 milhōes de pneus, sendo gerados 106 milhões de pneus usados $[1,11]$. O volume de pneus usados teve um decréscimo em função do declínio de vendas no mercado de reposição dos pneus novos. A tendência da geração de pneus usados para os próximos anos é que exceda 100 milhões de pneus. Durante este período, ocorreu um declínio na utilização de pneus usados como combustível nos fornos de clínquer, em virtude da redução de empresas privadas e a adoção da utilização de outros resíduos. Ocorreu uma redução de 12,72\% da utilização de pneus usados como combustível na indústria siderúrgica, em relação a 2002. Além disso, ocorreu uma redução dos pneus usados como combustível em caldeiras médias e pequenas em função da mudança da legislação. Todas estas situações resultaram em uma redução de 22,1\% na valorização energética, em relação a 2002. Por outro lado, ocorreu um aumento de $181 \%$ nas exportações de pneus para reutilização, reforma e resíduos de borracha, em relação a 2002. A figura 4 mostra a reciclagem de pneus no Japão no período de 1994 a 2007.

Os três principais mercados para a reciclagem de pneus usados no Japão são [1]:

- valorização energética dos pneus. Os pneus são utilizados como combustíveis alternativos em fornos de clínquer, em caldeiras, na indústria de papel, siderúrgicas, metalúrgicas e termoelétricas, representando $44 \%$ do total reciclado, ou seja, 45,32 milhões de pneus. No Japão 
iniciou-se o uso de pneus inservíveis para substituir o carvão, em alto-fornos e fornos elétricos. Em 2000, foram utilizadas
60.000 toneladas de pneus inservíveis, o que corresponde a 12 milhões de pneus de automóvel [12];

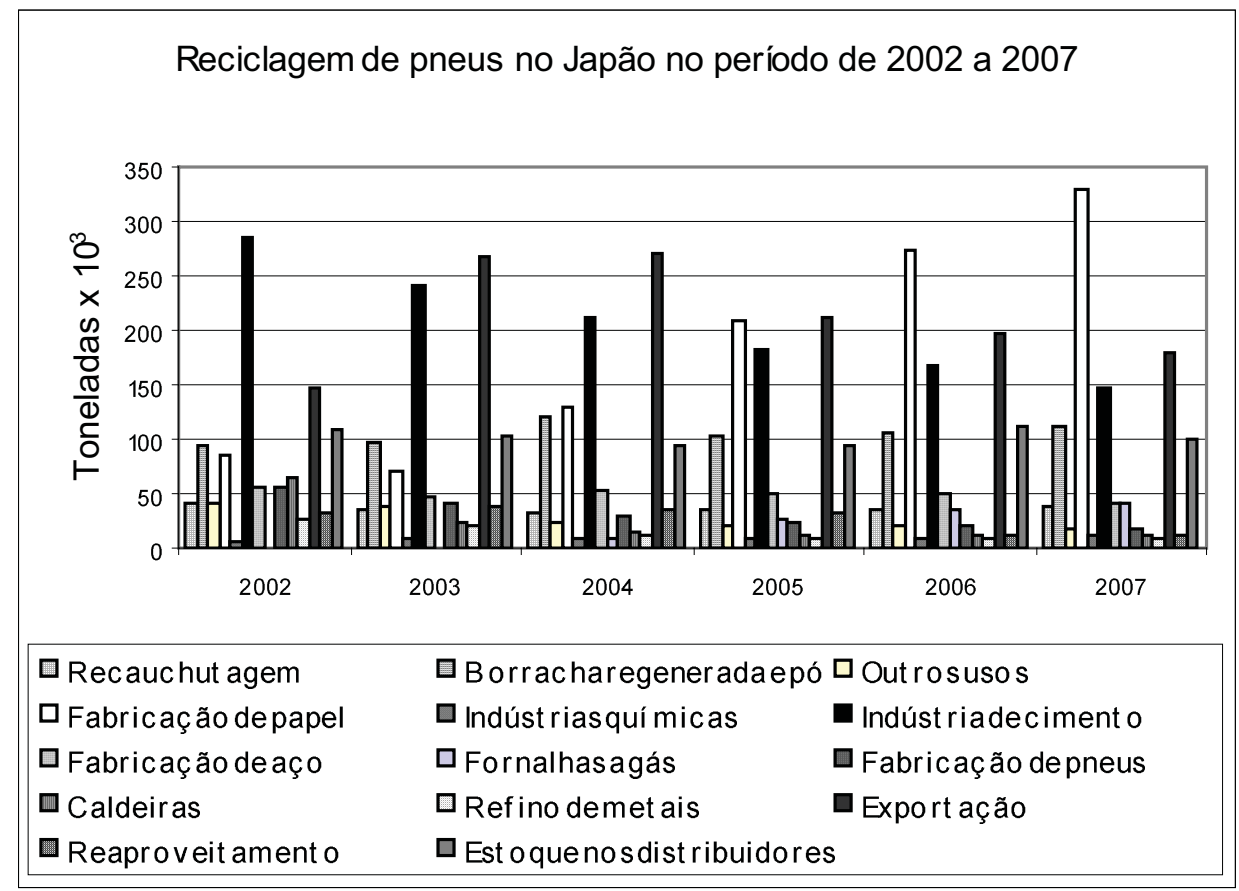

Figura 4- Reciclagem de pneus no Japão, no período de 2002 a 2007 [1].

- reutilização. Utilização de pneus usados para a recauchutagem; pó-de-borracha em aplicações na construção civil, asfalto-borracha entre outras, representando $17 \%$ do total reciclado, ou seja, 17,51 milhões de pneus. No Japão, em 2003, foram recauchutados 1,105 milhões de pneus de ônibus e caminhão;

- exportação de pneus usados para o reutilização e recauchutagem, que representa $26 \%$ do total reciclado, ou seja, 26,78 milhões de pneus;

\section{LEGISLAÇÃO BRASILEIRA SOBRE A RECICLAGEM DE PNEUS}

O Brasil foi o primeiro país na América Latina a regulamentar a disposição de pneus

Em 26 de agosto de 1999, foi aprovada a resolução nº 258/99 do CONAMA (Conselho Nacional do Meio Ambiente) [13] que instituiu a responsabilidade do produtor e do importador pelo ciclo total do produto, ou seja, a coleta, o transporte e a disposição final. Desde 2002, os fabricantes e importadores de pneus devem coletar e dar a destinação final para os pneus usados. Os distribuidores, revendedores, reformadores e consumidores finais são co-responsáveis pela coleta dos pneus usados, os quais devem colaborar com a coleta [13].

A partir de 2002, para cada 4 pneus produzidos ou importados (novos ou reformados) um pneu inservível deveria ser reciclado. A partir de 2003, a relação deveria ser de dois pneus produzidos ou importados (novos ou reformados) para um pneu inservível reciclado. Em 2004, a proporção foi de um pneu produzido ou importado novo para um pneu inservível reciclado. Em 2005, a proporção foi de 4 pneus produzidos ou importados novos, cinco pneus usados deveriam ser reciclados; e, para cada 3 pneus importados reformados de qualquer tipo deveriam ser reciclados 4 pneumáticos usados. As relações dos anos de 2005 a 2007 foram idênticas.

Em 2005, a resolução no 258/99, o CONA$\mathrm{MA}$, com base na experiência adquirida no período, reexaminou com o IBAMA (Instituto Brasi- 
leiro do Meio Ambiente e dos Recursos Naturais Renováveis), as normas e procedimentos desta resolução.

A forma de cálculo para determinar a quantidade de pneus a serem reciclados, no período de 2002 a 2007, está descrita abaixo:

$$
\mathrm{Q}=(\mathrm{P}+\mathrm{I}-\mathrm{E}) \times \mathrm{F}
$$

$Q$ = quantidade a ser reciclada;

$\mathrm{P}=$ produção de pneus novos;

$\mathrm{I}=$ importação de pneus novos;

$\mathrm{E}=$ exportação de pneus novos;

$F=$ Fator. Em 2002: 0,25; 2003: 0,5; 2004: 1;

2005: 1,25; 2006: 1,25, 2007: 1,25.

A Instrução Normativa $\mathrm{n}^{-}$8, de 15 de maio de 2002 do IBAMA [14], instituiu os procedimentos para o cadastramento de fabricantes, importadores de pneumáticos, processadores e destinadores de pneus inservíveis. Além disso, determinou as respectivas equivalências em peso para cada tipo de pneu existente, sendo: pneu de bicicleta: 0,45 kg; motocicleta: $2,5 \mathrm{~kg}$; automóvel: $5 \mathrm{~kg}$; camioneta: $12 \mathrm{~kg}$; ônibus e caminhão: 40 $\mathrm{kg}$; trator: $41 \mathrm{~kg}$; pneus fora de estrada, utilizados para nivelamento, movimentação, carregamento e compactação: $84 \mathrm{~kg}$.

A Instrução Normativa no 21 , de 25 de setembro de 2002 do IBAMA criou-se um mecanismo de compensação para os pneus exportados, ou seja, para cada pneu enviado ao exterior, ou o seu equivalente em peso, inclusive aqueles que equipam veículos importados, reduz-se um pneu da cota de reciclagem [15].

A Instrução Normativa nº 96, de 30 de março de 2006 do IBAMA [16], institui o Cadastro Técnico Federal de Atividades Potencialmente Poluidoras ou Utilizadoras de Recursos Ambientais, para registro obrigatório de pessoas físicas ou jurídicas que se dedicam às atividades potencialmente poluidoras ou à extração, produção, transporte e comercialização de produtos potencialmente perigosos ao meio ambiente, assim como de produtos e subprodutos da fauna e flora.

A resolução no 301/02 do CONAMA, de 21 de março de 2002 [17]. Altera e inclui os seguintes itens na resolução no $258 / 99$, que passam a vigorar com a seguinte redação:

- a importação de pneus usados é proibida pelas resoluções $\mathrm{n}^{-} 23$, de 12 de dezem- bro de 1996, e no 235 , de 7 de janeiro de 1998;

- se faz necessário o controle do passivo ambiental gerado pelos pneus usados oriundos de veículos automotores e bicicletas;

- as regras desta resolução, aplicam-se aos pneus usados, de qualquer natureza, que ingressarem em território nacional por força de decisão judicial. berá:

Ainda em relação aos pneus importados ca-

- à SECEX (Secretária de Comércio Exterior), a atribuição de informar o IBAMA, bimestralmente, a relação das empresas e as quantidades de pneus importados;

- as empresas importadoras devem comprovar a destinação final dos pneus inservíveis junto ao IBAMA.

Apesar de ser proibida a importação de pneus usados, os pneus entram no Brasil através de liminares.

\subsection{MUDANÇAS NA LEGISLAÇÃO BRASILEIRA}

Desde 2004, foi formado um grupo de trabalho para tratar da revisão da resolução CONAMA no 258/99. Este grupo é formado pelo IBAMA, fabricantes de pneus, reformadores, cimenteiras, recicladores e organizações ambientalistas.

Há uma série de propostas apresentadas pelo grupo de trabalho, que serão apresentadas e discutidas a seguir:

\subsubsection{Associação dos fabricantes}

As propostas dos fabricantes para a mudança da resolução no $258 / 99$ do CONAMA são [18]:

- os pneus inservíveis foram divididos em: pneus inservíveis e pneus inservíveis disponíveis. Os pneus inservíveis disponíveis são aqueles que não são de propriedade particular e que não é reaproveitado no mercado para outros fins, e se encontram a disposição para a destinação correta. Este fato se deu devido à dificuldade em convencer o consumidor 
no momento da troca a deixar os seus pneus nas lojas das revendas e distribuidores;

- a quantidade de pneus inservíveis a serem recolhidos no ano não tem relação direta com a quantidade produzida;

- que o acesso aos pneus inservíveis é limitado e restrito em função de serem de propriedade de particulares;

- os pneus inservíveis não podem ser utilizados para o processo de reforma;

- que parte dos pneus novos após a sua utilização, ainda possuem valor agregado e podem ser utilizados em processos de transformação / destinação, tais como: combustível alternativo para fornos de clínquer e caldeiras, matéria-prima em indústrias de artefatos de borracha e regenerados, laminaçóes no caso dos pneus convencionais ou diagonais, coprocessamento de pneus inservíveis com a rocha de xisto pirobetuminoso e outras destinações;

- deve ser considerada como destinação ambientalmente adequada de pneus inservíveis, a utilização em muro de arrimo, recifes artificiais, proteção de encostas (geotécnia), fossa séptica, disposição em aterro sanitário, desde que triturados, e quando não houver outra opção.

Analisando-se essas propostas, podem-se destacar as seguintes observaçôes:

- os pneus usados devem ser separados em servíveis ou inservíveis antes de serem destinados para o co-processamento, laminação, entre outras aplicaçôes. Os pneus servíveis devem ser destinados ao processo de reforma e, como acontece no Japão e países membros da Comunidade Européia, a atividade de reforma é considerada na estatística da reciclagem. No Brasil, a reforma de pneus usados não é regulamentada como uma atividade de reciclagem. Outro fato importante, dos itens a serem regulamentados como destinação ambientalmente correta, não foi citada a utilização da borracha triturada na pavimentação asfáltica e quando se cita disposição em aterros deve ser tratado como nos países membros da Co- munidade Européia, ou seja, deve ser proibida a disposição dos pneus inteiros ou triturados nos aterros;

- os consumidores que se beneficiam com a utilização dos pneus devem dar a sua parcela de contribuição, participando ativamente do processo de coleta e destino até os ecopontos e ecobases, que são pontos de recepção e armazenamento temporário dos pneus usados;

- as lojas de revenda e distribuidores poderiam dar um desconto ao consumidor no momento da troca dos pneus usados por novos, desde que os pneus usados tivessem as condições mínimas para a reforma;

- a geração de pneus inservíveis ocorre de forma irregular em todo o país, mas não existe nenhum levantamento realizado sobre a quantidade gerada, por município, estado. Deve ser feito um inventário nacional, abordando a geração, disposição e quantidade de pneus em aterros, lixões, entre outros. Nos Estados Unidos a cada dois anos é realizado um inventário dos pneus gerados e descartados em aterros em cada estado;

- não foi citado na proposta dos fabricantes, mas deve haver um incentivo maior a pesquisas para desenvolvimento de novos produtos, mercados para os produtos reciclados. Além disso, pesquisas devem ser realizadas para o aprimoramento da logística reversa dos pneus pós-consumo.

\subsubsection{Associação dos reformadores}

As propostas dos reformadores para a mudança da resolução no 258/99 do CONAMA são [19]:

- os processos de reforma ficam dispensados da coleta e destino final dos pneus inservíveis, com a condição da utilização dos pneus usados coletados em todo o território nacional;

- para cada pneu importado reformado, de qualquer tipo, cinco pneus inservíveis deverão ser coletados e destinados;

- redução de $50 \%$ da coleta e destino dos pneus inservíveis em todo o território 
nacional, nos anos de 2005, 2006 e 2007, sendo que em 2008 será feita uma avaliação pelo IBAMA;

- reavaliação a partir de 2008, pelo CONAMA e IBAMA da quantidade de pneus coletadas e destinados, normas e procedimentos, avaliação dos efeitos das importações de pneus usados, que são utilizados como matéria-prima pela indústria de reforma de pneus;

- ao contrário da proposta dos fabricantes de pneus no Brasil, a responsabilidade pela geração dos pneus é do fabricante, no momento da sua concepção;

- estabelecer um prazo de carência aos fabricantes de pneus, em função da vida útil dos pneus. Como exemplo, os pneus produzidos em 2005 devem ser coletados em 2008. A fiscalização para os pneus importados novos ou usados e a comprovação da contrapartida ambiental deve ser feita no momento da liberação aduaneira.

- Analisando-se essas propostas, podem-se destacar as seguintes observações:

- para cada pneu reformado importado a contrapartida é de 5 pneus inservíveis. Deve ser feita a mesma consideração para os pneus usados importados;

- os pneus inservíveis utilizados como combustível alternativo e matéria-prima para a fabricação do cimento não deveriam ser considerados como resíduos;

- quem se beneficia com a utilização dos pneus do início ao término da vida útil deve ser o responsável junto com à indústria por coletar e dar a destinação correta;

- o prazo de carência em função da vida útil dos pneus não garante que após três anos exista a mesma quantidade de pneus usados. A vida útil de um pneu depende de vários fatores: pavimento, alinhamento e balanceamento dos pneus, excesso ou falta de pressão de ar no pneu, entre outros;

- segundo a ABIP (Associação Brasileira da Indústria de Pneus Remoldados), são importados pneus usados para o processo de reforma de pneus de automóvel, caminhonete, ônibus e caminhão em função dos seguintes fatores: carência de quantidade de carcaças de boa qualidade no País, em razão da má conservação das ruas, estradas. Não foi levado em conta o baixo poder aquisitivo da população, que utiliza o pneu além do permitido pela lei, falta de quantidade suficiente de pneus usados coletados no País, com baixo custo, entre outros;

- deve haver um incentivo para a realização de pesquisas, desenvolvimento de novos produtos e mercados para os produtos reciclados.

\subsubsection{Fabricantes de cimento}

As propostas dos fabricantes de cimento para a mudança da resolução no $258 / 99$ do CONAMA são [20]:

- interesse em utilizar os pneus inservíveis em fornos de clínquer como combustível alternativo e matéria-prima para a fabricação do cimento;

- os fornos de clínquer possuem alta capacidade de destruição e controle rigoroso das emissões;

- a destruição de pneus inservíveis em fornos de clínquer é a tecnologia viável do ponto de vista ambiental.

Analisando-se essas propostas, podem-se destacar as seguintes observações:

- os pneus inservíveis quando alimentados nos fornos de clínquer, substituem de 10 a 30\% os combustíveis não-renováveis;

- redução do custo da fabricação de cimento com o co-processamento de pneus inservíveis;

- a malha de aço que faz parte da construção do pneu, durante o processo de destruição térmica é incorporada ao clínquer, ou seja, substitui parte da matéria-prima;

- existe um custo cobrado pelas cimenteiras para o co-processamento dos resíduos, este custo varia em função do tipo de resíduo, poder calorífico, entre outros fatores;

- os pneus devido o alto poder calorífico, o mesmo comparado com o coque de petróleo, deveria ser considerado como 
combustível e não um resíduo. Os pneus inservíveis deveriam ser vendidos para a indústria de cimento, o montante arrecadado poderia financiar a cadeia de reciclagem de pneus usados no país;

- deve ser realizado um estudo para a obtenção de crédito de carbono com o coprocessamento de pneus.

\subsubsection{Organizações Ambientalistas}

As propostas das organizações ambientalistas para a mudança da resolução no 258/99 do CONAMA são [21]:

- foi considerado o princípio da convenção da Basiléia, que trata do movimento transfronteiriço de resíduos, o qual o Brasil é signatário. Qualquer país que seja signatário tem o direito soberano de proibir a entrada ou depósito de resíduos estrangeiros em seu território;

- a transferência de passivo ambiental de um país para o outro, não deve ser permitida;

- o ingresso de pneus para reforma e posterior devolução ao país de origem deve ser autorizado pelo IBAMA, e deve ser feito um monitoramento do ingresso, trânsito e devolução dos pneus reformados ao país de origem;

- a prestação do serviço de recapagem e recauchutagem é isenta da obrigação de coleta dos pneus;

- o consumidor deverá entregar o pneu a ser descartado ao revendedor, distribuidor, nos ecopontos e ecobases. O consumidor pode manter a posse do pneu após o término da vida útil, mas deve fazê-lo de forma que não ponha em risco o meio ambiente e a saúde pública. A responsabilidade do consumidor não afasta a coleta dos pneus após o término da vida útil e a entrega a algum agente da cadeia de reciclagem de pneus;

- os revendedores, distribuidores, ecopontos ou ecobases, devem receber todos os pneus descartados entregues pelos consumidores;

- a obrigação dos fabricantes, importadores e remoldadores de pneus obedecerá a seguinte proporção: um pneu descartado para cada pneu fabricado; um pneu descartado para cada pneu novo importado; e um pneu inservível para cada dois pneus remoldados;

Visando o aprimoramento do processo de coleta de pneus em todo o território brasileiro, os fabricantes, importadores e remoldadores devem:

- criar centrais de recepção e armazenamento temporário dos pneus (ecopontos, ecobases, entre outros);

- divulgar amplamente a localização das centrais de recepção dos pneus (jornais, revistas, televisão, internet, entre outras)

- incentivar os consumidores a entregarem os pneus nos ecopontos, ecobases, revendas e distribuidores de pneus;

- incentivar estudos para a melhoria de toda a cadeia de reciclagem de pneus;

- desenvolver ações de articulação dos diferentes agentes da cadeia de reciclagem de pneus (coleta, triagem, pré-tratamento, transporte e destinação final dos pneus).

Analisando-se essas propostas, podem-se destacar as seguintes observações:

- no caso do processo de reforma de pneus, só serão isentos do processo de coleta e destinação final, as empresas que coletarem os pneus usados no país;

- a entrega voluntária dos pneus pelos consumidores deve ter algum incentivo por parte dos fabricantes, importadores e remoldadores, desde que os pneus tenham as condições mínimas de serem reformados. Os pneus considerados inservíveis devem ser retidos nos pontos de troca. Os distribuidores e revendas devem se adequar a esta necessidade, antes da aprovação da resolução;

- a proporção para a reciclagem de pneus deve ser mantida conforme a resolução CONAMA no 258/99;

\section{COMPARAÇÃO ENTRE A LEGISLAÇÃO INTERNACIONAL E BRASILEIRA}

$\mathrm{Na}$ tabela 1 é apresentada uma análise comparativa entre as legislações para a reciclagem de pneus no Brasil, Estados Unidos, países membros 
da Comunidade Européia e Japão, abordando as regulamentaçôes, taxas, incentivos e a base de cálculo para a reciclagem.

Observa-se que não existe incentivo para a reciclagem de pneus no Brasil. Além disso, a reutilização, a reforma e a exportação de produtos fabricados com borracha reciclada de pneus não são atividades regulamentadas.

A atividade de reforma de pneus nos Estados Unidos não é considerada como atividade de reciclagem e não faz parte da estatística de reciclagem. A reforma de pneus é considerada como uma atividade que prolonga a vida útil dos pneus e tem uma enorme contribuição com respeito à redução da geração de pneus usados [5]. Por outro lado, no Japão e nos países membros da Comunidade Européia, a atividade de reforma de pneus é considerada como atividade de reciclagem $[1,9,11]$.

Verifica-se que nos Estados Unidos e nos países membros da Comunidade Européia existem incentivos por parte de alguns países para incentivar a reciclagem de pneus, criar novos mercados para os produtos reciclados

A base de cálculo para a meta de reciclagem de pneus nos Estados Unidos, países da Comunidade Européia e Japão baseia-se na disponibilidade efetiva dos pneus, enquanto que no Brasil a base de cálculo é a produção de pneus.

Tabela 1 - Comparação da legislação para a reciclagem de pneus no Brasil, Estados Unidos, Comunidade Européia e Japão [1,2, 4,6, 22-23] (Adaptada ref. 22).

\begin{tabular}{|c|c|c|c|c|}
\hline Destinação Final & Brasil & Estados Unidos & $\begin{array}{l}\text { Comunidade } \\
\text { Européia }\end{array}$ & Japão \\
\hline $\begin{array}{c}\text { Utilização de pneus } \\
\text { usados como combustíveis } \\
\text { alternativos }\end{array}$ & $\begin{array}{l}\text { Parcialmente } \\
\text { regulamentada }\end{array}$ & Regulamentada & Regulamentada & Regulamentada \\
\hline Aterros & $\begin{array}{l}\text { Não aceito (com } \\
\text { exceção) }\end{array}$ & $\begin{array}{l}\text { Aceito em } \\
\text { alguns estados }\end{array}$ & $\begin{array}{c}\text { Pneus inteiros até } \\
2003 \text { e triturados } \\
\text { até } 2006\end{array}$ & Não aceito \\
\hline Reutilização & Não aceito & Aceito & Aceito & Aceito \\
\hline $\begin{array}{c}\text { Exportação (pneus } \\
\text { usados) }\end{array}$ & Não aceito & Aceito & Aceito & Aceito \\
\hline Construção Civil & $\begin{array}{c}\text { Não } \\
\text { regulamentada }\end{array}$ & Regulamentada & Regulamentada & Regulamentada \\
\hline $\begin{array}{c}\text { Reforma (Recauchutagem, } \\
\text { Recapagem e } \\
\text { Remoldagem) }\end{array}$ & $\begin{array}{l}\text { Não } \\
\text { regulamentada }\end{array}$ & $\begin{array}{l}\text { Não } \\
\text { regulamentada }\end{array}$ & Regulamentada & Regulamentada \\
\hline Taxas e Incentivos & Não existe & $\begin{array}{l}\text { Existente em } \\
\text { alguns estados }\end{array}$ & $\begin{array}{l}\text { Existente em } \\
\text { alguns países }\end{array}$ & Existente \\
\hline $\begin{array}{l}\text { Base de cálculo para a } \\
\text { reciclagem de pneus }\end{array}$ & $\begin{array}{c}\text { (Produção + } \\
\text { Importação - } \\
\text { Exportação) x \% }\end{array}$ & $\begin{array}{l}\text { Disponibilidade } \\
\text { efetiva (mercado } \\
\text { de reposição) }\end{array}$ & $\begin{array}{l}\text { Disponibilidade } \\
\text { efetiva (mercado } \\
\text { de reposição) }\end{array}$ & $\begin{array}{l}\text { Disponibilidade } \\
\text { efetiva (mercado } \\
\text { de reposição) }\end{array}$ \\
\hline $\begin{array}{l}\text { \% cumprimento das } \\
\text { metas para a reciclagem } \\
\text { de pneus (Fabricantes e } \\
\text { Importadores de pneus } \\
\text { usados) }\end{array}$ & $\begin{array}{c}28,61 \%(2005) \\
\text { e 30,3\% (2006) } \\
\text { (Fabricantes) } \\
1,87 \%(2005) \text { e } \\
11,45 \%(2006) \\
\text { (em peso) } \\
\text { (Importadores) }\end{array}$ & $\begin{array}{l}86,6 \% \text { em } \\
\text { quantidade de } \\
\text { pneus }(2005)\end{array}$ & $\begin{array}{c}87 \%(2005) \\
(\text { em peso) }\end{array}$ & $\begin{array}{l}100 \% \text { em } \\
\text { quantidade de } \\
\text { pneus (2007) }\end{array}$ \\
\hline
\end{tabular}




\section{MERCADOS PARA A RECICLAGEM DE PNEUS}

No Brasil, foram produzidos em 2007, 57,3 milhões de pneus, importados 5,8 milhões de pneus e exportados 19,8 milhôes de pneus [24]. Podemos observar que ocorreu um aumento de $5,14 \%$ do volume de pneus produzidos, $10,3 \%$ do volume de pneus vendidos, e 5,9\% do volume de pneus exportados, quando comparado com 2006. Os principais canais de vendas de pneus no Brasil são:
- mercado de reposição e revenda com $40 \%$; exportação $30 \%$ e indústria automobilística e montadoras 30\% [24].

Podemos observar na figura 5, a produção, importação, exportação e as metas para a reciclagem de pneus no período de 2002 a 2007. O objetivo a ser reciclado no período de 2002 a 2007 foi o equivalente a 214,05 milhões de pneus de automóvel.

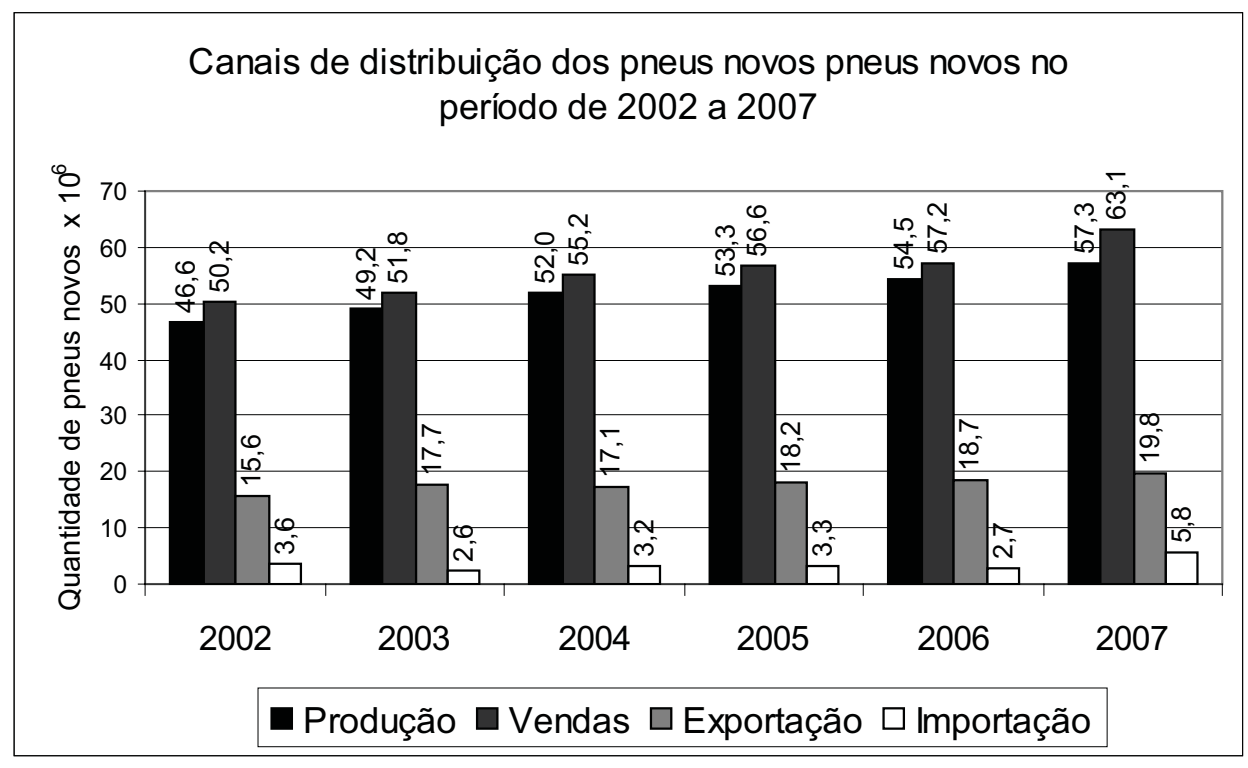

Figura 5 - Canais de distribuição dos pneus novos no período de 2002 a 2007, em quantidade de pneus.

Foram importadas, em 2005, 10,5 milhões de carcaças de pneus usados para a remoldagem e venda como pneus meia vida a um custo de US\$ 1,04 / carcaça de pneu usado [25]. Do total importado, 4 milhões de pneus foram remoldados, 3 milhôes de pneus recauchutados, 2 milhôes de pneus estocados e 1,5 milhôes de pneus colocados no mercado para venda como pneu meia vida [26].

A figura 6 apresenta os dados de importação de pneus usados no período de 1993 à setembro de 2008.

No período foram importados 63,51 milhões de pneus usados, com custo médio de US\$ 0,85. A tendência era o aumento da quantidade de pneus usados importados, mas como o órgão de apelação da OMC (Organização Mundial do Comércio), confirmou a proibição da importação de pneus usados para o processo de reforma [27-28]. Apesar da proibição da importação dos pneus usados em 2008, foram importados 2,95 milhões de pneus usados.
Existe uma série de vantagens para a importação de pneus usados pelas empresas que fazem a recauchutagem, recapagem e remoldagem, entre elas:

- baixo custo da importação;

- uma parte dos pneus importados para a reforma é vendida como pneus meia- vida. Os pneus são inspecionados quando chegam nas empresas que fazem a reforma. Devido o grande volume de pneus usados e o seu baixo custo, a empresa mantém uma escala constante de produção;

- como os pneus usados são importados a baixo custo, após o processo de reforma, os pneus têm preço de venda até $40 \%$ menor que um pneu novo;

- custo para a coleta, transporte e reforma de pneus é maior quando comparado com o custo de importação;

- $68 \%$ dos pneus coletados no país são inservíveis. 


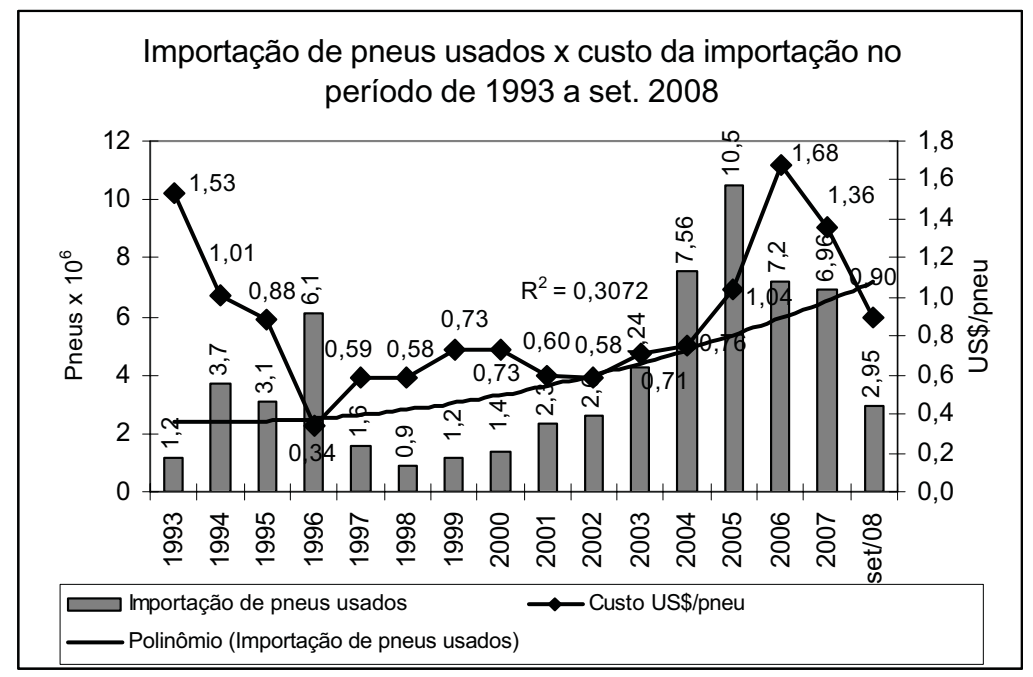

Figura 6 - Importação de pneus usados x custo de importação no período de 1993 a setembro de 2008 [25].

$\mathrm{Na}$ pesquisa realizada foi constatado que em 2006 foram reciclados no Brasil 240,62 mil toneladas de pneus inservíveis [23] o equivalente a 48,12 milhões de pneus de automóvel. Não estão inclusos neste levantamento as atividades de recauchutagem e remoldagem.

No período de 2002 a 2006 foram recicladas 805,26 mil toneladas de pneus inservíveis [23], o equivalente a 161,05 milhões de pneus de automóvel.

A figura 7 apresenta a porcentagem de destinação final dos pneus no Brasil, no período de 2002 a 2006. Em 2006, a atividade de laminação, trituração e fabricação de artefatos de borracha representou $50,02 \%$ do total reciclado; o co-processamento em fornos de clínquer nas indústrias de cimento, 35,73; a regeneração de borracha sintética e natural, 13,22; e a extração e tratamento de minerais, $1,03 \%$.

No processo de extração e tratamento de minerais, os pneus inservíveis triturados são adicionados à rocha de xisto pirobetuminoso, e através do processo de pirólise são separados o óleo, enxofre e o gás liquefeito de xisto.

A figura 8 apresenta a porcentagem para o cumprimento da resolução no $258 / 99$, no período de 2002 a 2006. Os fabricantes conseguiram atingir a meta apenas em 2002. Os importadores de pneus usados, não conseguiram atingir as metas no período de 2003 a 2006. Os importadores de pneus novos conseguiram atingir as metas no período de 2002 a 2006.

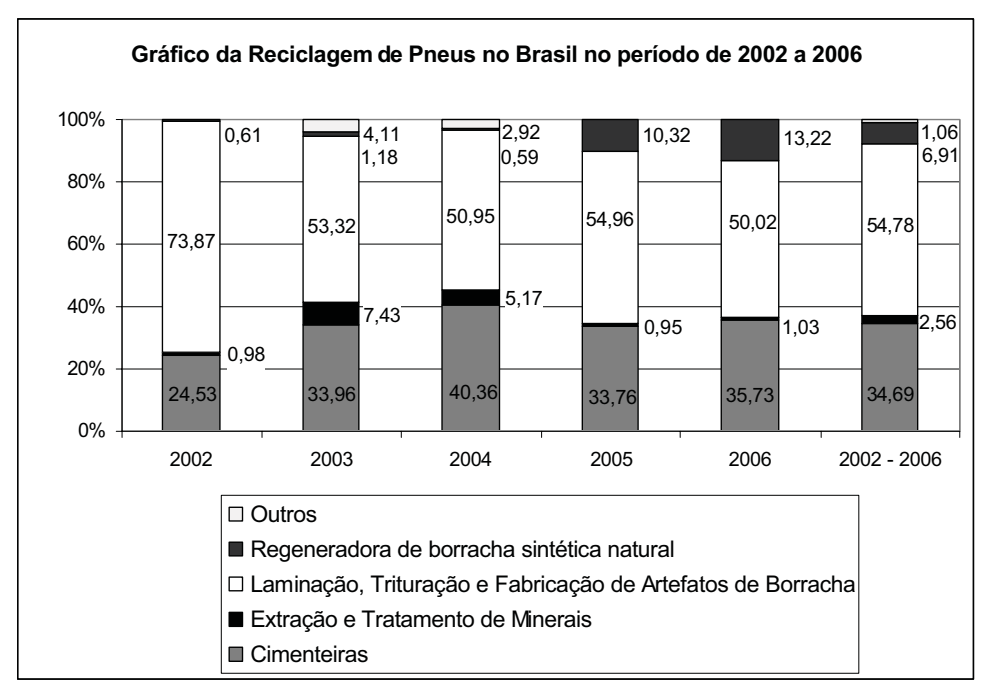

Figura 7 - Destino final dos pneus no Brasil no período de 2002 a 2006 [23]. 


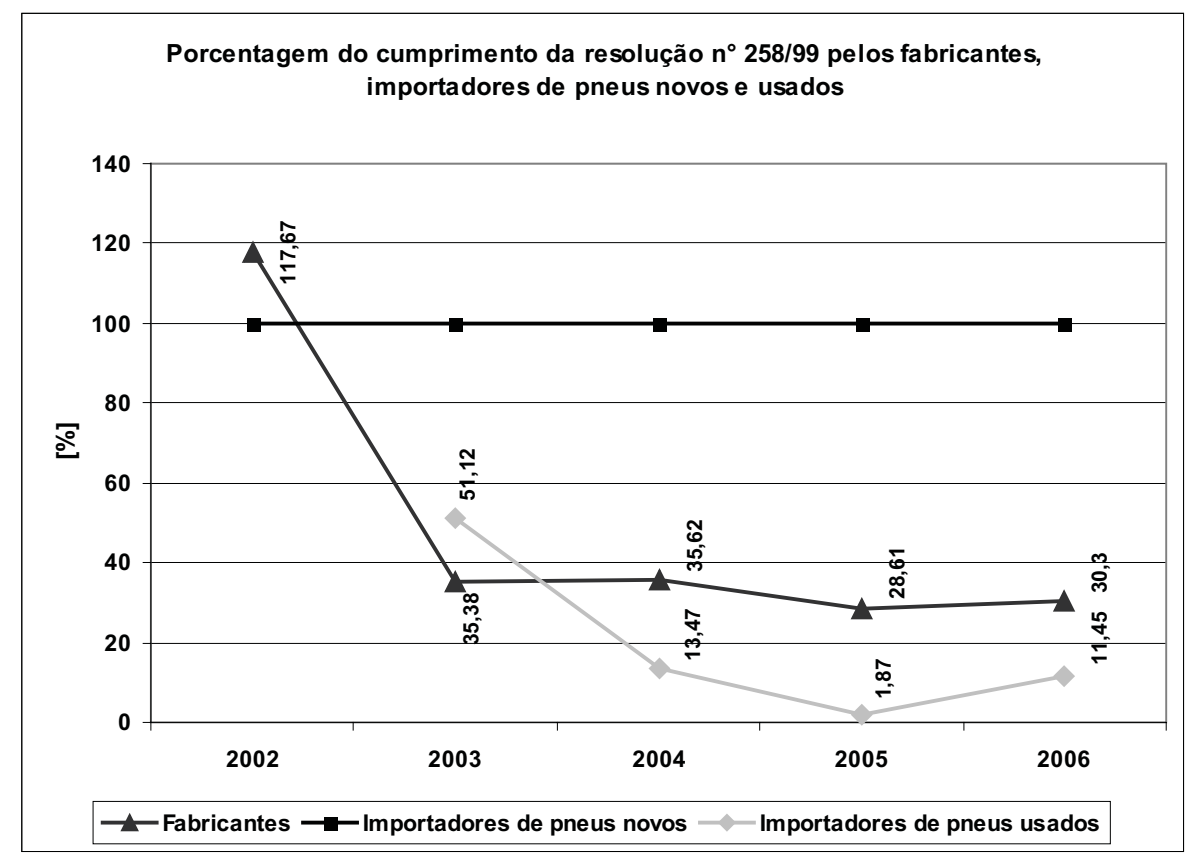

Figura 8 - Porcentagem do cumprimento da resolução n⿳o 258/99, pelos fabricantes, importadores de pneus novos e usados, no período de 2002 a 2006. [23].

\section{CONCLUSÃO}

Os Estados Unidos, Japão, e países membros da Comunidade Européia incentivam as pesquisas para o desenvolvimento de novos produtos e mercados para os pneus inservíveis. A base de cálculo para as metas de reciclagem de pneus nestes países é a disponibilidade efetiva, ou seja, o mercado de reposição.

Após a aprovação da Resolução no 258/99, ocorreu um avanço na cadeia de reciclagem de pneus no Brasil. Foi constatado que a logística reversa dos pneus pós-consumo é o principal elo desta cadeia. Além disso, não existe nenhum incentivo no Brasil para a realização da reciclagem de pneus.

Apesar do avanço da cadeia de reciclagem, os fabricantes não conseguiram atingir a meta de reciclagem entre 2003 e 2006, devido à falta de pneus inservíveis disponíveis e a forma de cálculo utilizada para a definição das metas. Os importadores de pneus usados não conseguiram atingir a meta no período de 2003 a 2007 . Não foi informado o resultado dos importadores de pneus usados pelo IBAMA, em 2002.

A Resolução no 258/99 encontra-se em revisão pelo CONAMA e IBAMA desde 2005, não existe uma previsão para a conclusão dos estudos por parte dos fabricantes, reformadores, organizaçōes ambientais, cimenteiras, CONAMA, IBAMA, entre outras.

A reforma de pneus no Brasil não é considerada como uma atividade de reciclagem. Nos países membros da Comunidade Européia e no Japão está atividade é regulamentada pela legislação e existem incentivos pelo governo para esta atividade.

Com relação à Resolução no 301/02, que proíbe a importação dos pneus usados, constatamos que os pneus usados entram no Brasil através de liminares judiciais. $\mathrm{O}$ custo para aquisição dos pneus usados é baixo e existe uma constância no fornecimento para a reforma de pneus. Além disso, parte dos pneus usados são vendidos como pneus meia-vida. Segundo as empresas de reforma não é viável a utilização das carcaças coletadas no Brasil, devido às condiçôes de utilização e o estado que elas se encontram. Deve ser incentivada a utilização dos pneus usados coletados em todo o território para o processo de reforma dos pneus. Além disso, os fabricantes, importadores, devem incentivar pesquisas de produto e mercado, para os pneus inservíveis. 


\section{REFERÊNCIAS BIBLIOGRÁFICAS}

[1] THE JAPAN AUTOMOBILE TYRE MANUFACTURERS ASSOCIATION. Tire industry of Japan 2008. [S.1.]: JATMA, 2008. 32 p.

[2] EUROPEAN TYRE RECYCLING ASSOCIATION. EU directives impacting on postconsumer tyres. Disponível em: <http://www. etra-eu.org>. Acesso em: 31 out. 2005.

[3] INTERNATION STANDARD ISO 22628. Road Vehicles - Recyclability and Recoverability - Calculation Method. Switzerland, feb. 15, 2002. 14p.

[4] RUBBER MANUFACTURES ASSOCIATION. Scrap tires market in the United States 2005 edition. Washington, DC, RMA, nov. 2006, 93p.

[5] HEITZMAN, M. Design and construction of asphalt paving materials with crumb rubber modifier. Washington, D.C.: TRB, 1992. (Transportation Research Record, 1339).

[6] RUBBER MANUFACTURES ASSOCIATION. State legislation november 2004. Disponível em: <http://www.rma.org>. Acesso em: 22 fev. 2006.

[7] THE EUROPEAN TYRE RECYCLING ASSOCIATION. Introduction to tyre recycling: 2004. Paris: ETRA, 2004. 16 p.

[8] SHULMAN, V. L. Post consumer tyres in expanded european union. Paris: ETRA, 2004. $31 \mathrm{p}$.

[9] EUROPEAN ASSOCIATION OF THE RUBBER INDUSTRY. End of life tyres and annual activy report $2004-2005$. Disponível em: <http://www.blic.be>. Acesso em: 10 jan. 2006.

[10] CONSORZIO PER IL RECUPERO E IL RIUTILIZZO DEI PNEUMATICI. Le tecnologie. Disponível em: <http://www.ecopneus.it/it/ sect2/page23.html>. Acesso em: 20 fev. 2008.

[11] PORTLAND CEMENT ASSOCIATION. Sustainable manufacturing fact sheet: tire de- rived fuel. Disponível em: <http://www.cement. org/bookstore/results_quicksearch.asp >. Acesso em: 7 maio 2005.

[12] NIPPON STEEL CORPORATION. Nippon steel sustainability report 2007. Disponível em: <http://www0.nsc.co.jp/kankyou/>. Acesso em: 05 jan. 2008.

[13] BRASIL. Conselho Nacional do Meio Ambiente. Resolução n. 258, de 26 de agosto de 1999. Disponível em: <http://www.mma.gov.br/ port/conama/res/res99/res25899.html>. Acesso em: 10 jan. 2003.

[14] BRASIL. Instituto Brasileiro do Meio Ambiente e dos Recursos Naturais Renováveis. Instruçáo normativa n. 8, de 15 de maio de 2002. Brasília: IBAMA, 2002. 3 p.

[15] BRASIL. Instituto Brasileiro do Meio Ambiente e dos Recursos Naturais Renováveis. Instrução normativa n. 21 , de 25 de setembro de 2002. Brasília: IBAMA, 2002. 2 p.

[16] BRASIL. Instituto Brasileiro do Meio Ambiente e dos Recursos Naturais Renováveis. Instrução normativa n. 96, de 30 de março de 2006. Brasília: IBAMA, Diário Oficial da União, seção 1, p. 179-187.

[17] BRASIL. Conselho Nacional do Meio Ambiente. Resolução n. 301, de 21 de março de 2003. Brasília: Conama, 2003. 2 p.

[18] ASSOCIAÇÃO NACIONAL DA INDÚSTRIA DE PNEUMÁTICOS. Proposta da ANIP para a revisão da resolução n. 258/99 do CONAMA. Disponível em: <http://www.mma.gov. br> Acesso em: 20 abr. 2008.

[19] ASSOCIAÇÃO BRASILEIRA DA INDÚSTRIA DE PNEUS REMOLDADOS. Revisão da Resolução Conama 258/99 - 14 a . Reunião da Câmara Técnica de Saúde, Saneamento Ambiental e Gestão de Resíduos - 19.07.05. Disponível em: <http://www.mma.gov.br>Acesso em: 20 fev. 2006.

[20] ASSOCIAÇÃO BRASILEIRA DE CIMENTO PORTLAND. Ofício no 383/04/GP da Assembléia Legislativa do Estado de Santa Catari- 
na: parecer sobre os pneus inservíveis. Disponível em: <http://www.mma.gov.br> Acesso em: 20 fev. 2006.

\section{[21] ASSOCIAÇÃO DE PROTEÇÃO AO MEIO} AMBIENTE CIANORTE. Proposta, de revisão da resolução 258/99, de consenso entre o relator da matéria, Ministério das Cidades e Apromac na reunião de 20/07/05, com ajustes da Apromac em 21/07/05: dispõe sobre a prevenção à poluição causada por pneus descartados e sobre a respectiva cadeia de coleta e destinação ambientalmente adequada e segura. Disponível em: <http://www.mma. gov.br> Acesso em: 20 fev. 2006.

[22] ASSOCIAÇÃO NACIONAL DA INDÚSTRIA DE PNEUMÁTICOS. Destinação adequada de pneus inservíveis. Disponível em: <http:// www.mma.gov.br>Acesso em: 20 nov. 2005.

[23] INSTITUTO BRASILEIRO DO MEIO AMBIENTE E DOS RECURSOS NATURAIS RENOVÁVEIS. Dados estatísticos da reciclagem de pneus no Brasil. Brasília, setembro, 2008, 3p.
[24] ASSOCIAÇÃO NACIONAL DA INDÚSTRIA DE PNEUMÁTICOS. Dados estatísticos sobre o mercado de pneus novos no Brasil. Disponível em: <http://www.anip.com.br>. Acesso em: 17 out. 2008.

[25] ALICEWEB. Dados estatísticos sobre a importação de carcaças e pneus recauchutados. Disponível em: <http://aliceweb.desenvolvimento.gov.br>. Acesso em: 17 out. 2008.

[26] SILVA, C. Apesar de vetada, importação de pneus usados cresce 40\%. O Estado de São Paulo. São Paulo, 16 fev. 2006. p. B8.

[27] NINIO, M. OMC aprova veto do Brasil à importação de pneus usados. São Paulo, Folha de São Paulo, 4 dez. 2006, p. B4.

[28] LAFER, C. OMC - a decisão sobre os pneus reformados. São Paulo, O Estado de São Paulo, 20 jan. 2008, p. A2. 